\title{
Arabismos documentados em Ataliba, o Vaqueiro
}

\section{Arabic loanwords in Ataliba, $o$ Vaqueiro}

Samantha de Moura Maranhão https://orcid.org/0000-0003-4741-5628

Resumo: Este estudo sobre os arabismos da obra Ataliba, o Vaqueiro, (CASTELO BRANCO, 2012 [1880]) busca responder à questão: o que caracteriza arabismos do português brasileiro, conforme representados na referida obra? Testaram-se as hipóteses: 1. são sobretudo arabismos ibéricos; 2. ocorrem em campos semânticos variados e 3. predominam os substantivos com estrutura mórfica simples. O aporte teórico é da Filologia Árabo-Românica, realizando-se coleta manual dos dados, cuja origem árabe foi corroborada em dicionários diversos (VARGENS, 2007; CORRIENTE, 2003; MICHAËLIS, 1998; FERREIRA, 1999; HOUAISS; VILLAR, 2001). Um glossário com as lexias, informações gramaticais e etimológicas, acepção textual e abonação apresenta os dados. Os resultados corroboram as hipóteses testadas.

Palavras-chave: Português Brasileiro; Arabismos; Piauí; Lexicologia; Lexicografia.

Abstract: This study about Arabisms in 'Ataliba, o Vaqueiro' (CASTELO BRANCO, 2012 [1880]) aims to answer the research problem: what characterizes Arabic loanwords in Brazilian Portuguese? The tested hypothesis were: 1. most of the loanwords are Iberian Arabisms; 2. the Arabisms are organized in different semantic fields and 3. nouns with a simple morphological structure are more numerous. This research is based on Arabo-Romance Philology, with the data manually collected and the Arabic origin of the words confirmed in different dictionaries (VARGENS, 2007; CORRIENTE, 2003; MICHAËLIS, 1998; FERREIRA, 1999; HOUAISS; VILLAR, 2001). A 
Keywords: Brazilian Portuguese; Arabisms; Piauí; Lexicology; Lexicography.

\section{Introdução}

Este estudo tem por objeto arabismos do português brasileiro, especificamente aqueles documentados na obra romântica Ataliba, o Vaqueiro, publicada por Francisco Gil Castelo Branco no ano de 1880 pela Tipografia Cosmopolita, do Rio de Janeiro.

Tem por objetivo identificar os arabismos em uso, conhecer os campos semânticos em que se organizam e a estrutura mórfica com que se apresentam. Busca responder, portanto, a questão: o que caracteriza arabismos do português do Nordeste, representado na obra Ataliba, o Vaqueiro? As hipóteses testadas são: 1. a de que se trata sobretudo de arabismos ibéricos, de antiga integração no sistema lexical da língua portuguesa; 2. a de que os arabismos ocorrem em campos semânticos variados, quais o do vestuário, o da alimentação, o de utensílios e o de animais e 3. a de que os substantivos com estrutura mórfica básica estão numericamente melhor representados.

Os fundamentos teóricos são da Filologia Árabo-Românica, realizando-se, no que respeita à metodologia da pesquisa, a coleta manual dos dados, cuja origem árabe foi corroborada em produtos lexicográficos especializados (FRANCA, 1994; VARGENS, 2007; CORRIENTE, 2003; CORRIENTE, 2013), bem como em dicionários gerais de língua portuguesa (MICHAËLIS, 1998; FERREIRA, 1999; HOUAISS; VILLAR, 2001). Apresentam-se os dados em glossário, cujos verbetes trazem, para cada lexia documentada, informações gramaticais e abonação extraídas do corpus.

\section{Metodologia}

Com o propósito de se analisarem arabismos do português do Brasil, vimos levantando empréstimos e estrangeirismos árabes em diferentes obras brasileiras, ficcionais ou acadêmicas. Para o estudo que ora apresentamos, realizamos a coleta de dados no romance romântico Ataliba, o Vaqueiro, da autoria do escritor piauiense Francisco Gil Castelo Branco, 
valendo-nos da $10^{a}$ edição, revista e atualizada, com base na $3^{a}$ edição, pelos professores Fabiano de Cristo Rios Nogueira, Maria Gomes Figueiredo dos Reis, Maria do Socorro Rios Magalhães, Maria do Perpétuo Socorro Neiva Nunes do Rêgo, responsáveis por estudo bibliográfico e pela revisão do texto da obra. Esta edição veio a lume em Teresina em 2012 pela Fundação Quixote.

A publicação original foi divulgada em folhetim para, no ano de 1880, ser reunida em volume e publicada pela Tipografia Cosmopolita, no Rio de Janeiro. O enredo está ambientado no sertão do Piauí fronteiriço ao Ceará, documentando, portanto, uma variedade regional do português brasileiro, mormente no que concerne ao vocabulário, designativo da realidade extralinguística nele descrita.

Realizamos manualmente a coleta dos empréstimos de origem árabe, com o concurso de produtos lexicográficos especializados (FRANCA, 1994; CORRIENTE, 2003; VARGENS, 2007; CORRIENTE, 2013) e gerais (MICHAËLIS, 1988; FERREIRA, 1999; HOUAISS, VILLAR, 2001).

Observada a norma comum a que o vocabulário pertence, optamos pela simplificação dos verbetes, os quais trazem a lexia na entrada, na sua forma masculina singular para substantivos, adjetivos e particípios passados com função adjetiva e na forma infinitiva para os verbos. Não verificadas nas abonações as referidas formas não marcadas, estas vêm apresentadas entre colchetes.

Além das lexias levantadas, os verbetes apresentam a classe de palavra dos arabismos e abonações. As abreviaturas empregadas nos verbetes são: m. masculino; f. feminino; s. substantivo; adj. adjetivo; adv. advérbio; v. verbo; part. pas. com função adj. particípio passado com função adjetiva. As abonações foram transcritas como constam na edição supracitada, entre aspas, com três pontos entre parênteses para indicar recortes no texto. Eventualmente, para garantir clareza na leitura do fragmento, inserimos o sujeito da oração entre colchetes. Em seguida da abonação, indica(m)-se a(s) página(s) em que se localiza, na edição consultada, como se pode ver nos exemplos abaixo.

[Alforje] - s.m. "(...) suspendendo à mão direita um par de alforjes." (p. 49);

[Arrebatado] - part. pas. com função adj. "Teresinha arrebatada nesta atitude (...)." (p. 71).

[Embaraçar] - v. “(...) sua presença embaraçava Ataliba (...).” (p. 45).

Faca - s.f. "[A fera] buscava espedaçar entre as suas garras de bronze o aço puro da faca (....." (p. 100). 
Ainda considerando a norma comum a que pertencem os arabismos analisados, optouse por descrever e/ou comentar mais pormenorizadamente apenas alguns dos vocábulos levantados, seja pelo seu uso menos frequente, seja por alguma peculiaridade mórfica.

\section{Arabismos em Ataliba, o Vaqueiro}

O levantamento dos empréstimos árabes documentados na obra Ataliba, o Vaqueiro (CASTELO BRANCO, 2012) resultou no glossário abaixo, com 56 lexias.

[Achaque] - s.m. "Não; isto são os meus achaques (...)." (p.83).

[Açoitar] - v. "(...) horrores da desgraça que açoitava já o teto da sua cabana." (p. 82); "Um vento tépido, sufocante, (...) açoitava as árvores, arrebatando-lhes as últimas folhas tostadas (...)." (p. 87); “A onça (...) açoitou o chão com a cauda (...)." (p. 99-100).

Açougue - s.m. “(...) vamo-nos embora deste açougue." (p. 92).

Açúcar - s.m. "Uma libra de açúcar mascavinho... garrafa de azeite doce..." (p. 54).

[Afagar] - v. "Depois, mudando o tom e afagando a filha, disse (...)." (p. 93); "Ataliba (...) tomou ao colo sua noiva, afagava-a, (...) beijou-a (...)." (p. 98).

[Afago] - s.m. "(...) habituado aos seus afagos, estava deitado aos seus pés (...)." (p. 70).

Ajoujar - v. "Ataliba foi (...) buscar o carretão (...) composto por duas rodas (...) presas em um grande eixo, donde parte um braço para se ajoujar os animais que o arrastavam" (p. 93).

Alazão - s.m. "Mas o alazão tem estado aguado (...)." (p. 37); "O alazão espetou-se no toco?" (p. 38); “(...) não se esquecendo também do alazão de Ataliba." (p. 82); “Depois de preparar os animais e arranjar com a rede e o surrão do africano um cômodo para a moreninha à garupa do alazão (...), o vaqueiro fez um sinal à moça (...)." (p. 106-107); "Ataliba descera Teresinha, apresentando o alazão os mesmos indícios de fraqueza e rolando extenuado poucos passos adiante." (p. 110).

[Alfinete] - s.m. "Duas meadas de linha... duas cartas de alfinetes... um papel de agulhas curtas." (p. 53).

[Alforje] - s.m. "(...) suspendendo à mão direita um par de alforjes." (p. 49); "Cassange (...) atrapalhou-se nos alforjes e foi beijar a poeira do chão." (p. 49); É que o velho nunca as esquecia, encontrava sempre no fundo das algibeiras, ou no antro dos alforjes, uma fruta, um brinquedo, um agrado qualquer (...)." (p. 51); "Adiante do preto, sobressaíam os enormes alforjes (...)." (p. 
57); O trem do africano, os arreios, o surrão, a borracha de campo bem provida e os alforjes estavam ali pendurados (...)." (p. 104); “(...) ele sacou dos alforjes um maço de algodão (...)." (p. 104).

Algazarra - s.f. "O alarido atingiu a última nota superior da algazarra (...)." (p. 49).

Algibeira - s.f. "Estão aqui na minha algibeira." (p. 40); "Ataliba sacara da algibeira um rolo de pavio de cera de abelhas (...)." (p. 43); "É que o velho nunca as esquecia, encontrava sempre no fundo das algibeiras, ou no antro dos alforjes, uma fruta, um brinquedo, um agrado qualquer (...)." (p. 51).

Algodão - s.m. “(...) e o decantado papa-fogo (...), contendo algodão e outras matérias inflamáveis." (p. 43); "Cassange, que havia despido o vestuário de couro e ficado em ceroulas de algodão da terra (...) armava e temperava o seu berimbau (...)." (p. 54); "Nestes momentos, (...) uma mescla de algodão que a brisa suspende nos ares (...), tudo (...) fala ao coração (...).". (p. 69); “(...) o cabo de uma faca sobressaía do cós da ceroula de algodão (...)." (p. 71); "A sua espingarda, levando no ponto de mira um capuz de algodão para melhor firmar a pontaria, ia com a coronha descansada no estribo (....." (p. 94); "(...) ele sacou dos alforjes um maço de algodão (...)." (p. 104); “(...) ela embebia o algodão na aguardente diluída (...)." (p. 104).

Almofada - s.f. "Eram a almofada de renda e o estojo de costura da moreninha, o seu cabedal produtivo." (p. 45); “(...) e fingia não prestar atenção ao esquecimento em que permaneciam a sua almofada e os outros seus trabalhos domésticos." (p. 61).

[Alvoroçado] - part. pas. com função adj. "Deodata (...) alvoroçada abraçou o sertanejo (...)" (p. 48).

Alvoroço - s.m. "Cassange, porém, atribuía todo este alvoroço à sua chegada (...)." (p. 49); “(...) os perus (...) abrem as caudas em sinal de alvoroço (...)." (p. 59).

Âmbar - s.m. "De repente, Teresinha sentiu calafrios, ficou pálida como o âmbar (...)." (p. 111). Amofinar - v. "Não vale a pena a gente amofinar-se." (p. 62).

[Aquilatar] - v. "Teresinha não aquilatava com precisão a hediondez da desgraça que rugia sobre aquelas cabeças (...)." (p. 69).

[Arfar] - v. "Os seus seios arfavam (...)." (p. 60).

[Arrebatado] - part. pas. com função adj. "Teresinha arrebatada nesta atitude (...)." (p. 71).

Arrebatamento - s.m. "O velho obedeceu-lhe, mas a evocação da desventura arrefecera o seu arrebatamento (...)." (p. 92).

[Arrebatar] - v. “(...) quando ela convulsiva, furtiva e assustada por esse acesso que agitava seu noivo, arrebatando-a igualmente, levantou-se (...)." (p. 71); “Um vento tépido, sufocante, (...) açoitava as árvores, arrebatando-lhes as últimas folhas tostadas (...)." (p. 87). 
[Arrefecer] - v. "O velho obedeceu-lhe, mas a evocação da desventura arrefecera o seu arrebatamento (...)." (p. 92).

Arrozal - s.m. "(...) assemelhava-se à frágil haste do arrozal (...)." (p. 86).

Azeite - s.m. "Preparava-os à luz do azeite (...)." (p. 45); "Uma libra de açúcar mascavinho... garrafa de azeite doce..." (p. 54); "A paca que Dionísio trouxera figurava, ensopada com azeite de coco, entre um leitão e dois frangos assados." (p. 64).

Azul - adj. “(...) porque reluziam acolá seis pratos azuis, seis colheres de chumbo, dois talheres, quatro tigelas de várias dimensões (...)" (p. 45); “(...) o céu tingia-se de cores vivas e resplandecentes, destacando-se um fundo azul (.....” (p. 58); “(...) línguas de fogo pulverizandoos em chamas azuis (...)." (p. 102).

[Baldado] - part. pas. com função adj. “(...) mas baldados foram os seus esforços.” (p. 85).

[Beduíno] - s.m. "(...) percorrem as grandes distâncias do sertão, como beduínos no deserto." (p. 73).

[Cabide] - s.m. "Vários ganchos (...) substituíam as funções de excelentes cabides." (p. 44).

Ceroula - s.f. "Cassange, que havia despido o vestuário de couro e ficado em ceroulas de algodão da terra (...) armava e temperava o seu berimbau (...)." (p. 54); "(...) o cabo de uma faca sobressaía do cós da ceroula de algodão (.....” (p. 71); “Depois, (...) arregaçaram as ceroulas e continuaram o trabalho (...)." (p. 77).

Cofre - s.m. "(...) as filigranas que formam o cofre sagrado onde ela encerra o seu segredo (...)". (p. 39).

Debalde - adv. "A morena perturbou-se e debalde procurou ocultar-Ihe a sua comoção (...)" (p.70).

[Embaraçado] - part. pas. com função adj. “(...) a moreninha sentia-se embaraçada na presença do vaqueiro (...)." (p. 62); "Teresinha ficou embaraçada com esta ordem." (p. 90).

[Embaraçar] - v. “(...) sua presença embaraçava Ataliba (...)." (p. 45).

Enxaqueca - s.f. "Ela queixava-se de forte enxaqueca (....)" (p. 83).

Faca - s.f. "Ataliba (...) foi procurar a faca (...)." (p. 98); "O vaqueiro (...) puxou da bainha a sua faca e aguardou o inimigo" (p. 100); "Em vão, também, o sertanejo procurava introduzir a sua faca nas entranhas da fera (....." (p. 100); "[A fera] buscava espedaçar entre as suas garras de bronze o aço puro da faca (....." (p. 100); "Bramia a fera quando a ponta da faca lhe cortava, embora de leve, as carnes (....)." (p. 101); "[A fera] (...) depara sempre com a ponta da faca a frustrar-Ihe a agilidade (...)." (p. 101); "A faca do vaqueiro engolfara-se por fim no coração da fera (....)." (p. 101); “Dionísio, levando como lembranças do vaqueiro a sua faca e a espingarda, assentou o africano no animal em que viera." (p. 115). 
[Façanha] - s.f. "(...) contam as suas façanhas e os triunfos obtidos nas matas e nos campos (...)." (p. 61).

Facão - s.m. “(...) na cintura trazia o seu paraíba, isto é, um facão de má qualidade metido na bainha da sola (...)." (p. 71).

[Fanar] - v. "Mas vira fanarem-se as boninas silvestres, sumirem-se as rolinhas do terreiro, secarem-se as águas do terreiro (...)" (p. 69).

Folgazão - adj. "Humilde e folgazão, prestimoso e leal, o africano era estimado de todos (...)." (p. 51); "O africano, apesar do seu gênio folgazão, ficou acabrunhado um momento (...)." (p. 63).

Garrafa - s.f. "Uma libra de açúcar mascavinho... garrafa de azeite doce..." (p. 54); "A velha levou a garrafa ao nariz e prosseguiu no seu exame." (p. 54); “(...) nem havia quem o excedesse quando (...) vazava a garrafa de cachaça." (p. 61); "(..) ele sacou dos alforjes (...) uma garrafa de cachaça (...)." (p. 104); "O africano (...) enchendo a sua garrafa de cachaça (...) entregou o restante da borracha de campo a seu amo (...)." (p. 106); “(...) o africano repartira a sua insignificante ração d'água, restando-Ihe apenas um pouco no fundo da garrafa (...)." (p. 110); “Em vão o africano corria atrás do vaqueiro para lhe entregar as últimas gotas d'água que continha a sua garrafa (...)." (p. 111).

[Garrafão] - s.m. “(...) voltou Cassange, trazendo no arção da sela um garrafãozinho de cachaça (...)." (p. 63).

Gibão - s.m. “(...) o seu gibão e o seu chapéu com trancelim e borlas de fios de cor eram de finas peles de bezerro (...)." (p. 36); “(...) o gibão, atado ao pescoço por duas correiazinhas, pendia-lhe negligentemente sobre as largas espáduas (...)." (p. 71); "Ataliba foi selar o cavalo, vestir o gibão e as perneiras (...)." (p. 93); "O vaqueiro (...) meteu o seu chapéu de couro por cima do gibão (...)." (p. 100).

Laranja - adj. "O africano meditou um instante - então descobriu-se o garrote laranja?" (p. 55). [Mascarado] - part. pas. com função adj. “(...) tremeluzindo em um sorriso meigo nos lábios mascarados da donzela todas as suas virtudes (...)." (p. 71).

[Nacarado] - part. pas. com função adj. "(...) o horizonte resplandecente de nuvens nacaradas atraía a atenção (...)." (p. 34).

Papagaio - s.m. "Olha, olha este papagaio, rapariga, como está parecido." (p. 53).

Surrão - s.m. “(..) ele apareceu na sala carregando ao ombro esquerdo um surrão de carneiro (...)." (p. 49); "Cassange encavacou (...) e disfarçou o seu fiasco, abrindo o surrão e tirando os embrulhos da tia Deodata." (p. 49); "O seu berimbau ali vinha sobre dois surrões (...)." (p. 57); "Ele trazia ao ombro (...) o seu surrão contendo toda a sua riqueza (...)." (p. 71); "O trem do 
africano, os arreios, o surrão, a borracha de campo bem provida e os alforjes estavam ali pendurados (...)." (p. 104); “Depois de preparar os animais e arranjar com a rede e o surrão do africano um cômodo para a moreninha à garupa do alazão (...), o vaqueiro fez um sinal à moça (....." (p. 106-107).

Tabaco - s.m. “(...) entupia a cada instante as fossas nasais de fartas pitadas do seu formidável corniboque, aparelho idêntico ao papa-fogo, contendo porém tabaco em vez de isca (....." (p. 83).

Tagarelice - s.f. "Depois de ouvir uma tremenda repreensão da tia Deodata por causa da sua tagarelice (...)." (p. 63).

Tamborete - s.m. “(...) satisfeito, ele indicava o veadinho debaixo do tamborete.” (p. 55); “(..) a moça apanhou instintivamente o pavio que ardia no tamborete e correu após o velho." (p. 101-102).

Taramela - s.f. "Mas a tia Deodata (...), com as mãos nas cadeiras, deu à taramela." (p. 55).

Tarefa - s.f. "(...) entoando alegres cantigas (...) preenchia a tarefa do serão quotidiano (...)." (p. $45)$.

Tigela - s.f. “(...) porque reluziam acolá seis pratos azuis, seis colheres de chumbo, dois talheres, quatro tigelas de várias dimensões (....)." (p. 45); “Nas tigelas transbordava a obrigativa coalhada (....." (p. 64); "Vou beber uma tigela de fedegoso misturado com um nadinha de café e duas cascas de fumo (...)." (p. 83).

Xale - s.m. “(...) estava enrolada no seu famoso xale de lã (...)." (p. 83).

Corriente (2003, p. 106) dicionariza ajoujo ajoijo como arabismo português com a mesma acepção com que ocorre em nosso corpus, 'estrutura para emparelhar animais'. Vocábulo de origem grega, em que originalmente significava 'esposo', evocando a ideia de 'par', foi introduzido no árabe por intermédio da língua aramaica, chegando ao árabe andalusino e deste para o português. Corriente (2003, p. 106) informa os derivados intrarromânicos do português ajoujar e desajoujar.

Alforje ocorre em Ataliba, o vaqueiro (CASTELO BRANCO, 2012) com a mesma acepção medieval, de 'bolsa dupla para se carregar na garupa de cavalgaduras' (CORRIENTE, 2003, p. 164). Trata-se de forma presente em diversos falares ibéricos, nomeadamente aragonês, castelhano, catalão, navarro e galego.

Sobre algibeira, Corrientes (2003, p. 171) informa tratar-se de 'bolso', como mesmo sentido do étimo árabe, acrescido de sufixo românico, o que o torna um vocábulo híbrido.

Amofinar encontra-se em Corriente (2003, p. 212, 393), como derivado 
intrarromânico, de mofino 'desgostoso', cujo étimo árabe significava 'ofendido'.

Para arrefecer, 'perder interesse, diminuir', Corriente (2003, p. 418) aponta derivação intrarromânica pautada em refece ( ant. rafez), 'vil, miserável', e arrefece, ' a baixo preço'. Tem origem em étimo andalusino com o significado de 'barato'.

Corriente (2003, p. 254) dicionariza as formas portuguesas de balde, em balde e os derivados intrarromânicos (a)baldar, abaldeirado, baldio e baldo(so) como cognatos do ár. and. bátil 'inútil, gratuitamente' < ár. clás. bātil(an) 'inutil(mente)'. No árabe andalusino já funcionava como adjetivo ou advérbio. Na obra Ataliba, o vaqueiro (CASTELO BRANCO, 2012), verifica-se o seu sujeito às flexões de gênero e número da morfossintaxe da língua importadora (baldados os seus esforços), bem como ocorre o advérbio debalde.

Corriente (2003, p. 315) afirma que fanar, 'mutilar, amputar', documentado em português e em galego, ainda apresenta problemas de estabelecimento de étimo. Parece relacionar-se o seu conteúdo à prática judaico-islâmica da circuncisão, considerada uma mutilação pelos adeptos do cristianismo. É provável origem em étimo árabe com sentido de 'circuncisão' acrescido dos morfemas românicos de infinitivo verbal da primeira conjugação portuguesa.

Já sobre gibão, peça de vestuário, é variante de aljuba 'veste de manga curta', com diferentes vias de transmissão: árabe andalusina esta última (ár. and. aljúbba < ár. clás. jubbah), Itália ou Provença a primeira (neoár. jibbah), cujo étimo existe em diversos dialetos, mas não no árabe andalusino (CORRIENTE, 2003, p. 334, 180).

Surrão está dicionarizado em Corrientes (2003, p. 441) como 'mochila', tratando-se de aumentativo românico do ár. and. súrra < ár. cl. surrah 'bolsa'.

Taramela, 'trava de porta', é forma cognata de tagarela, esta última, originalmente, um 'espantalho sonoro', com evolução semântica e provavelmente por analogia com formas fônicas próximas designativas do novo significado (CORRIENTE, 2003, p. 453).

Mencione-se apenas que o nome do cavalo de uma das personagens da obra Ataliba, o vaqueiro (CASTELO BRANCO, 2012), Fidalgo, embora forma neolatina, é um decalque árabe, língua em que são comuns construções como filho da noite para 'ladrão' e filho de algo para 'fidalgo, homem nobre, aristocrata', literalmente, 'filho com algum recurso material/bens' (LAPESA apud MARANHÃO, 1996). Na referida obra, ocorre, por exemplo, "Trotando no seu Fidalgo" à p. 72.

Os 56 arabismos colhidos na obra Ataliba, o vaqueiro (CASTELO BRANCO, 2012) são arabismos ibéricos de antiga integração ao sistema lexical da língua portuguesa, como atestam a flexão de gênero e de número em substantivos, adjetivos e particípios passado com função 
adjetiva (afagos, embaraçada, nacaradas, tigelas) e a derivação (arrozal de arroz, baldado de baldio, de onde também debalde; tagarelice de tagarela; garrafãozinho de garrafa, os verbos afagar de afago; aquilatar de quilate, etc.), características de adaptação morfológica.

Dentre as classes de palavras representadas, estão 36 substantivos ([achaque], açougue, açúcar, [afago], alazão, [alfinete], [alforje], algazarra, algibeira, algodão, almofada, alvoroço, âmbar, arrebatamento, arrozal, azeite, [beduíno], [cabide], ceroula, cofre, enxaqueca, faca, facão, façanha, garrafa, [garrafão], gibão, papagaio, surrão, tabaco, tagarelice, tamborete, taramela, tarefa, tigela, xale); 10 verbos ([açoitar], [afagar], ajoujar, amofinar, aquilatar, arfar, arrebatar, arrefecer, [embaraçar], [fanar]]; 06 particípios passados com função adjetiva ([a/voroçado], [arrebatado], [baldado], [embaraçado], [mascarado], [nacarado]); 03 adjetivos (azul, folgazão, laranja) e 01 advérbio (debalde).

Quadro 01 - Classes de palavras dos arabismos em Ataliba, o vaqueiro.

\begin{tabular}{|c|c|c|}
\hline CLASSE DE PALAVRAS & NÚMERO DE ITENS & PERCENTUAL \\
\hline Substantivos & 36 & 64 \\
\hline Verbos & 10 & 18 \\
\hline $\begin{array}{c}\text { Adjetivos e } \\
\text { Particípios com função } \\
\text { adjetiva }\end{array}$ & 09 & 16 \\
\hline Advérbio & & \\
\hline TOTAL & 01 & 100 \\
\hline
\end{tabular}

Fonte: A autora.

Dos processos de contato cultural resultam empréstimos lexicais, designativos de referentes da cultura estrangeira, de modo que a categoria gramatical melhor representada costuma ser a dos substantivos. Observe-se que, dentre os arabismos descritos, esta é a classe a que pertence a maior parte. Com efeito, somados, verbos, adjetivos e particípios com função adjetiva atingem $36 \%$ do total, pouco mais do que a metade dos substantivos, que totalizam $64 \%$.

Adquirem-se, inicialmente, formas básicas, as quais, após sofrerem adaptação fonológica (estrutura silábica, acento) e morfológica (gênero, plural), estão disponíveis no léxico 
e sujeitas a formação de novas palavras (por meio dos processos de composição e de derivação), designando novos referentes, quando também podem entrar em ação processos semânticos (expansão semântica). Têm-se, então, terminologias, neologismos, etc., na dinâmica das línguas em uso, tão vivas quanto as comunidades que as falam.

Dentre os arabismos ora analisados, 32 das 56 formas são básicas ([achaque], açougue, açúcar, [afago], alazão, [alfinete], [alforje], algazarra, algibeira, algodão, almofada, alvoroço, âmbar, azeite, azul, [beduíno], cabide, ceroula, cofre, enxaqueca, faca, façanha, garrafa, gibão, laranja, papagaio, surrão, tabaco, taramela, tarefa, tigela, xale), em oposição às 24 formas derivadas ([açoitar], [afagar], ajoujar, [alvoroçado], amofinar, [aquilatar], [arfar], [arrebatado], arrebatamento, [arrebatar], [arrefecer], arrozal, [baldado], debalde, [embaraçado], [embaraçar], facão, [fanar], folgazão, [garrafão], [mascarado], [nacarado], tagarelice, tamborete). Não se verificam arabismos resultantes de processo de composição.

Quadro 02 - Estrutura mórfica dos arabismos em Ataliba, o vaqueiro.

\begin{tabular}{|c|c|c|}
\hline ESTRUTURA MÓRFICA & NÚMERO DE ITENS & PERCENTUAL \\
\hline Formas básicas & 32 & 57 \\
\hline Formas derivadas & 24 & 43 \\
\hline TOTAL & 56 & 100 \\
\hline
\end{tabular}

Fonte: A autora.

É comum nos arabismos portugueses a presença do artigo aglutinado ao substantivo, como consequência de processo diacrônico verificado no árabe andalusino, isto é, na variedade oral, popular, da língua árabe falada no território muçulmano da Península Ibérica, Alandalus (NOLL apud MARANHÃO, 2011, p. 113-114). A população cristã falante do romandalusino, o romance de Alandalus, exerceu importante papel na transmissão de arabismos aos falares cristãos nortenhos. Àquele momento, constituíam adstratos, com inevitáveis interferências mútuas, os romances ibéricos (inclusive o judeu-espanhol), variedades distintas do árabe (andalusino, norte-africano, corânico), o hebraico e o latim (MARANHÃO, 2018, p. 129-134).

A maioria dos substantivos de origem árabe documentados em Ataliba, o vaqueiro (CASTELO BRANCO, 2012), entretanto, não apresenta o fenômeno da aglutinação do artigo. Dos 36 itens lexicais em questão, 15 trazem o artigo aglutinado ([achaque], açougue, açúcar, [afago], alazão, [alfinete], [alforje], algazarra, algibeira, algodão, almofada, alvoroço, 
arrebatamento, arrozal, azeite), contra 21 em que o referido processo não se verifica (âmbar, [beduíno], [cabide], ceroula, cofre, enxaqueca, faca, [façanha], facão, garrafa, [garrafão], gibão, papagaio, surrão, tabaco, tagarelice, tamborete, taramela, tarefa, tigela, xale). Este resultado sugere a herança de arabismos ibéricos adquiridos tanto por meio direto, oral, popular, quanto por meio indireto, de terminologias específicas, da química, da medicina e da administração. A intermediação de falantes do romance andalusino nas traduções do árabe para o latim concorreram para a ocorrência da aglutinação nas terminologias transmitidas pela escrita (LÜDTKE, 1974, p. 85 e HALL JR., 1971, p. 98 apud MARANHÃO, S. de M., 1996, p. 13).

Quadro 03 - Aglutinação do artigo nos arabismos de Ataliba, o vaqueiro.

\begin{tabular}{|c|c|c|}
\hline $\begin{array}{c}\text { AGLUTINAÇÃO DO } \\
\text { ARTIGO }\end{array}$ & NÚMERO DE ITENS & PERCENTUAL \\
\hline Com artigo aglutinado & 15 & 42 \\
\hline Sem artigo aglutinado & 21 & 58 \\
\hline TOTAL & 36 & 100 \\
\hline
\end{tabular}

Fonte: A autora.

Os arabismos em Ataliba, o Vaqueiro (CASTELO BRANCO, 2012) se distribuem por 14 campos semânticos, assim descritos:

i) Ações: [açoitar], [afagar], ajoujar, amofinar, [aquilatar], [arfar], [arrebatar], [arrefecer], [embaraçar], [fanar].

ii) Utensílios domésticos: [alfinete], almofada, [cabide], cofre, faca, facão, garrafa, [garrafão], tamborete, taramela, tigela.

iii) Vestuário e acessórios: [alforje], algibeira, ceroula, gibão, surrão, xale.

iv) Emoção, sentimentos e características psíquicas: [afago], [alvoroçado], [arrebatado], [baldado], [embaraçado], folgazão.

v) Ruído, confusão, estupefação: algazarra, alvoroço, arrebatamento, [façanha], tagarelice.

vi) Agricultura e seus produtos: açúcar, algodão, arrozal, azeite, tabaco.

vii) Características físicas: azul, laranja, [mascarado], [nacarado].

viii) Saúde: [achaque], enxaqueca.

ix) Animais: alazão, papagaio. 
x) Estabelecimento: açougue.

xi) Natureza: âmbar.

xii) Povo, etnônimo: [beduíno].

xiii) Trabalho, serviço: tarefa.

xiv) Modo: debalde.

A análise dos campos semânticos aponta a predominância de vocábulos designativos de referentes usuais no lar, seguidos por aqueles designativos de ações, pelas peças do vestuário e pelas emoções. Considerando-se a literatura sobre arabismos ibéricos medievais, observe-se que: o inventário de verbos decorrentes de derivação aumentou, pois para o Medievo fala-se apenas em recamar e no hoje descartado matar (VASCONCELOS, 1956, p. 304-305).

O vocabulário da vestimenta remete a peças já não mais em uso no século XXI, e que talvez demandem do leitor mais jovem uma consulta ao dicionário para lidar com a sua designação ([alforje], algibeira, surrão). O gibão é peça de uso rural, sertanejo, caricaturo do homem nordestino. O xale e as ceroulas são peças de uso de moradores de climas menos tórridos, embora os termos ainda integrem a língua comum.

Os campos da agricultura e seus produtos e dos utensílios domésticos são constituídos por vocábulos de uso corrente. Formas como folgazão e o uso com função adjetiva do particípio passado dos verbos elevam o número de arabismos com função qualificativa, quando para o português arcaico um dos poucos exemplos de adjetivo de origem árabe é mesquinho (VASCONCELOS, 1956, p. 304).

Uma análise quantitativa dos arabismos analisados por campo semântico é exposta no quadro 04, a seguir.

Quadro 04 - Campos semânticos dos arabismos de Ataliba, o vaqueiro.

\begin{tabular}{|c|c|c|}
\hline Campo Semântico & Número de itens & Percentual \\
\hline Utensílios domésticos & 11 & 19,6 \\
\hline Ações & 10 & 17,9 \\
\hline Vestuário e acessórios & 06 & 10,7 \\
\hline $\begin{array}{c}\text { Emoção, sentimentos, } \\
\text { características psíquicas }\end{array}$ & 06 & 10,7 \\
\hline Ruído, confusão, estupefação & 05 & 8,9 \\
\hline
\end{tabular}




\begin{tabular}{|c|c|c|}
\hline Agricultura e seus produtos & 05 & 8,9 \\
\hline Características físicas & 04 & 7,1 \\
\hline Saúde & 02 & 3,6 \\
\hline Animais & 02 & 3,6 \\
\hline Estabelecimento & 01 & 1,8 \\
\hline Natureza & 01 & 1,8 \\
\hline Povo, etnia & 01 & 1,8 \\
\hline Trabalho, serviço & 01 & 1,8 \\
\hline Modo & 01 & 100 \\
\hline TOTAL & 56 & \\
\hline
\end{tabular}

Fonte: A autora.

Comparando os arabismos coligidos em Ataliba, o vaqueiro (CASTELO BRANCO, 2012) com estudo de Sousa e Maranhão (2016) sobre arabismos ibéricos que no português brasileiro adquiriram novas acepções e estão dicionarizados com a marcação diassistêmica de "brasileirismo" no Léxico Português de Origem Árabe: subsídios para estudos de filologia (VARGENS, 2007), reiteramos o caráter conservador dos arabismos ora estudados.

Na herança ibérica "aclimatada", levantaram-se inicialmente 274 lexias, cuja análise semântica estendeu a 300 itens, devido à polissemia, perfazendo os brasileirismos cerca de $10 \%$ do total dos arabismos dicionarizados na obra de Vargens (2007).

Assim como os arabismos de Ataliba, o vaqueiro (CASTELO BRANCO, 2012), os substantivos constituíam a maioria das formas documentadas, entretanto, em percentual maior: $89,1 \%$ (contra 66\% em Ataliba, o vaqueiro). Por outro lado, adjetivos e verbos eram menos representados, com os percentuais de $7,3 \%$ e de 3,3\%, respectivamente, quando na obra piauiense perfazem $16 \%$ de adjetivos e 18\% de verbos. Em um intervalo de cerca de 130 anos, a derivação aumentou o número de arabismos na língua portuguesa.

Sobretudo a designação popular da fauna e da flora nativas do Brasil resultou na criação de numerosos compostos, os quais, com efeito, somam 127 itens lexicais e constituem $46,3 \%$ dos brasileirismos de origem árabe; seguidos de 78 formas derivadas, equivalentes a 28,5\% dos vocábulos, e apenas 62 formas básicas ou 22,6\% do total. Lembremos que, dentre 
os arabismos documentados em Ataliba, o vaqueiro (CASTELO BRANCO, 2012), sequer ocorrem formas compostas, constituindo as formas básicas $57 \%$ do total e as derivadas, $43 \%$. A composição é um processo mais simples e responsável pela criação lexical então analisada, aparentemente com o intuito de especializar os seres vivos numa classificação popular das espécies.

Em Sousa e Maranhão (2016, p. 65-76) figuram, a título de exemplo:

Açoita-cavalo - s.m. Nome de árvores do gênero luhea, da família das tiliáceas, cuja madeira serve para edificações e imobiliário

Algodão-bravo - s.m. Designação de duas plantas brasileiras, da família das malváceas e das concolvuláceas.

Algodão-cravo - s.m. Butuá-de-corvo. ${ }^{2}$

Algodão-da-praia - s.m. Planta brasileira, da família das malváceas, de flores amarelas, utilizadas na ornametação; algodoreiro-da-praia.

Algodão-de-açúcar - s.m. Algodão-doce.

Algodão-do-brejo - s.m. Fanfã. ${ }^{3}$

Algodão-do-mato - s.m. Butuá-de-corvo; algodoeiro-do-mato.

Algodãorana - s.f. Planta amazonense, da família das malváceas Pavonia paniculata, utilizada na indústria têxtil.

Algodoreiro-do-campo - s.m. Butuá-de-corvo.

Algodoim - s.m. Algodãozinho. ${ }^{4}$

Papagainho-roxo - s.m. Maitaca-roxa. ${ }^{5}$

Papagaio-caboclo - s.m. Papagaio-peito-roxo.

Papagaio-campeiro - s.m. Ave psitaciforme, da família dos psitacídeos Amazona ochrocephala (Gmel.), cujo habitat é o NO do Brasil e países limítrofes.

Papagaio-curraleiro - s.m. Papagaio-peito-roxo.

Papagaio-da-serra - s.m. Ave psitaciforme, da família dos psitacídeos Amazona preteri (Tem.), cujo habitat é o Uruguai e S do Brasil.

\footnotetext{
${ }^{2}$ Conforme Houaiss (2001), arbusto da família das bixáceas (Coclospermum insigne), nativo do Brasil, encontrado de PE a MG, em SP e no C.-O.)

${ }^{3}$ Planta (Hibiscus bifurcatus), segundo Houaiss (2001).

${ }^{4}$ Tecido de algodão, leve ou de baixa qualidade, de acordo com Houaiss (2001).

${ }^{5}$ Ave da família dos psitacídeos (Pionus menstruus), encontrado da Costa Rica à Bolívia e ao SE do Brasil, de acordo com Houaiss (2001).
} 
Papagaio-de-coleira - s.m. Anacã. ${ }^{6}$

Papagaio-do-mangue - s.m. Ave psitaciforme, da família dos psitacídeos Amazona amazônica (L), cujo habitat é o N e C do Brasil e países limítrofes.

Papagaio-do-peito-roxo - s.m. Psitaciforme, da família dos psitacídeos Amazona vinacea (kuhl.), cujo habitat é o S e E do Brasil.

Papagaio-grego - s.m. Papagaio-verdadeiro.

Papagaio-poaieiro - s.m. Papagaio-do-mangue.

Papagaio-urubu - s.m. Periquito-urubu

Papagaio-verdadeiro - s.m. Psitaciforme, da família dos psitacídeos Amazona aestiva (L.), cujo habitat é o E do Brasil.

Sobre os campos semânticos em que se organizam os brasileirismos,

\begin{abstract}
A análise dos campos semânticos pelos quais se distribuem os arabismos europeus com usos próprios do Brasil aponta predomínio do campo semântico da flora e agricultura (94 itens ou 31,3\% do total), seguido da culinária ( 31 tens, $10,33 \%$ do total) e da fauna, pesca, pecuária e montaria (com 30 itens, perfazendo $10 \%$ do total das formas analisadas). Verificaram- -se campos variados, como o de instrumentos musicais, de instrumentos e utensílios, de unidades de peso e medida, de coletivos e grandes quantidades, de geografia e acidentes geográficos, de substâncias medicinais, químicas ou de perfumaria, de engenharia, construção e habitação, de vida social, dentre outros. (SOUSA E MARANHÃO, 2016, p. 78-79)
\end{abstract}

Os brasileirismos integravam 28 campos semânticos, alguns dos quais coincidindo com os em que se organizam os empréstimos árabes de Ataliba, o vaqueiro (CASTELO BRANCO, 2012), a exemplo da fauna, agricultura e habitação, com destaque, dentre aqueles, para termos de áreas técnicas, como unidades de peso e medida, medicina, química e engenharia, não verificados no texto piauiense.

Diferentemente dos arabismos identificados em Ataliba, o vaqueiro, cujo conteúdo semântico é frequentemente o mesmo com que foi adquirido no Medievo, os arabismos com marcação diassistêmica de uso regional, do português do Brasil, adquiriram novas acepções, muitas das quais metafóricas e jocosas. Encontram-se, em Sousa e Maranhão (2016, p. 65-75),

\footnotetext{
${ }^{6}$ Ainda conforme Houaiss (2001), ave da família dos psitacídeos (Deroptyus accipitrus), nativa da AM.
} 
Açougue - s.m. 1. fig. Prostíbulo; 2. fig. Local utilizado para encontros amorosos, geralmente clandestinos.

Alforje - s.m. gír. Nariz grande e chato.

Almofadinha - s.m. Homem que se excede ao se vestir.

Almofadismo - s.m. 1. Elegância exagerada. 2. Modos e atitudes de almofadinha.

Arroz-de-festa - s.m. 1. Indivíduo que não perde festas. 2. Indivíduo que frequenta festas sem ser convidado; peru-de-festa; arroz-doce-de-festa; arroz-doce-de-pagode.

Cabide - s.m. Cavalo magérrimo.

Cabide ambulante - pop. Pessoa macérrima.

Cabide de empregos - Pessoa que tem muitos empregos.

[Garrafa] u.f. Conversar com a garrafa - pop. Ficar embriagado.

Papagaiada - s.f. pop. Exibição exagerada; papagaíce.

Inconteste parece a produtividade dos arabismos da língua portuguesa, adaptando-se ininterruptamente às necessidades comunicativas dos brasileiros, motivo pelo qual o seu uso deve ser sistematicamente investigado por linguistas.

\section{Conclusão}

A análise apenas realizada dos arabismos do português brasileiro documentados na obra romântica Ataliba, o Vaqueiro (CASTELO BRANCO, 2012), publicada originalmente em fins do século XIX pelo piauiense Francisco Gil Castelo Branco, permitiu-nos retomar as hipóteses, chegando às seguintes conclusões.

De fato, são sobretudo arabismos ibéricos, de antiga integração no sistema lexical da língua portuguesa, com adaptação morfossintática concluída, corroborando a primeira hipótese testada.

Sobre a sua distribuição por diferentes campos semânticos, como do vestuário, o da alimentação, o de utensílios e o de animais, também se pode corroborar a referida hipótese, uma vez que, com efeito, as formas levantadas integram mais de uma dezena de campos semânticos.

Por fim, sobre a maior incidência de substantivos com estrutura mórfica básica, a análise dos dados confirmou esta hipótese, a qual ratifica a origem e o uso de arabismos ibéricos medievais, em que predominam esta categoria gramatical e esta configuração morfológica 
(substantivos simples).

Observou-se, ainda, não predominarem acepções regionais, identificadas nos produtos lexicográficos como brasileirismos, tratando-se antes de usos iguais aos já documentados no português arcaico.

Novos estudos sobre arabismos do português brasileiro pautados em obras de autores piauienses estão em andamento, para divulgação em breve.

\section{Referências}

CASTELO BRANCO, Francisco Gil. Ataliba, o vaqueiro. 10. ed. Teresina: Fundação Quixote, 2012.

CORRIENTE, Federico. Los arabismos y otras voces médio-orientales del Dicionário Houaiss da Língua Portuguesa. Filologia e Linguística Portuguesa, v. 15, n. spe., p. 69-184, dez. 2013.

CORRIENTE, Federico. Diccionario de arabismos y voces afines en iberorromance. 2. ed. ampl. Madrid: Gredos, 2003. [Biblioteca Románica Hispánica, Fundada por Dámaso Alonso, Diccionarios, 22]

DICMAXI Michaëlis Português: moderno Dicionário da Língua Portuguesa, Versão 1.1. Amigo do Mouse Software Ltda., set. 2000. 1 CD-ROM.

FERREIRA, Aurélio Buarque de Holanda. Novo Aurélio século XXI: o dicionário da língua portuguesa. 3. ed. totalmente revista e ampliada. Versão 3.0. Rio de Janeiro: Lexikon Informática Ltda./Sonopress, 1999. 1 CD-ROM.

HOUAISS, Antônio; VILLAR, Mauro de Salles. Dicionário Houaiss da língua portuguesa. Versão 1.0.10. Rio de Janeiro: Objetiva, 2006. 1 CD-ROM.

MARANHÃO, Samantha de Moura. Arabismos portugueses no contexto multilinguístico da península ibérica medieval. Caligrama, v. 23, n. 2, p. 121-143, 2018.

MARANHÃO, Samantha de Moura. O registro de arabismos nos dicionários Novo Aurélio Século XXI, Dicionário Houaiss da Língua Portuguesa e Dicmaxi Michaëlis: moderno dicionário da língua portuguesa. 2011. 375 f. Tese (Doutorado em Linguística). Programa de Pós-Graduação em Linguística, Universidade Federal do Ceará, Fortaleza.

MARANHÃO, Samantha de Moura. Os arabismos nas receitas de medicamentos e nos regimentos relativos à saúde do 'Livro da Cartuxa'. 1996. 30 f. Trabalho de conclusão da disciplina Contatos Linguísticos na România (Mestrado em Letras). Instituto de Letras, Universidade Federal da Bahia, Salvador.

SOUSA, Francisco Barroso de; MARANHÃO, Samantha de Moura. Arabismos europeus no português brasileiro. Cadernos de Letras da UFF, Dossiê Línguas e Culturas em Contato, n. 53, p. 61-81, 2016.

VARGENS, João Baptista de Medeiros. Léxico português de origem árabe: subsídios para os estudos de filologia. Rio Bonito: Almádena, 2007.

VASCONCELOS, Carolina Michaëlis de. Fontes do léxico português: os elementos árabes. In:

VASCONCELOS, Carolina Michaëlis de. Lições de filologia portuguesa. Lisboa: Revista de Portugal, 1956. p. 299-310. 